\title{
Muscle activity during simulated work in the cold
}

\author{
Julie Renberg ${ }^{1 *}$, Per Øyvind Stranna Tvetene ${ }^{2}$, Øystein Nordrum Wiggen ${ }^{1}$, Karin Roeleveld ${ }^{2}$, Mireille Van Beekvelt ${ }^{2}$, \\ Hilde Færevik ${ }^{1}$
}

From 15th International Conference on Environmental Ergonomics (ICEE XV)

Portsmouth, UK. 28 June - 3 July 2015

\section{Introduction}

The abundance of natural resources in the Barents region is encouraging growth and development in the far North, exposing more workers to outside work in the cold (average temperature and wind velocity at Rognsundet in Finnmark last winter were $-2.6{ }^{\circ} \mathrm{C}$ and $9.8 \mathrm{~m} . \mathrm{s}^{-1}$, with extreme values of $-15.3^{\circ} \mathrm{C}$ and $27.5 \mathrm{~m} . \mathrm{s}^{-1}$ ). The aim of this study was to investigate the effect of realistic cold exposure on muscle activity, while wearing the cold-weather protective clothing used in the mining industry.

\section{Methods}

15 male volunteers performed simulated work at two ambient temperatures $\left(\mathrm{T}_{\mathrm{a}}\right):-15{ }^{\circ} \mathrm{C}$ and $5{ }^{\circ} \mathrm{C}$. The experimental protocol consisted of five test periods and four work periods with a total exposure time of two hours. The five 10-minute test periods started with a dynamic wrist flexion (DWF) exercise, followed by maximal voluntary contraction of the wrist flexor, elbow flexor and shoulder abductor. The four work periods consisted of manual work above head level ( $5 \mathrm{~min}$ ), manual work at hip height $(5 \mathrm{~min})$ and a lifting exercise $(5 \mathrm{~min})$. EMG was used to measure muscle activity, and nearinfrared spectroscopy (NIRS) measured local muscle metabolism. Heart rate (HR), skin and rectal temperatures $\left(\mathrm{T}_{\mathrm{re}}\right)$ were measured continuously. The protective clothing worn was identical under both environmental conditions.

\section{Results}

During the two hours of exposure at $-15^{\circ} \mathrm{C}$ compared to $5{ }^{\circ} \mathrm{C}$, mean skin temperature and finger skin temperature fell by $2.7^{\circ} \mathrm{C}$ and $10-15{ }^{\circ} \mathrm{C}$, respectively. Forearm skin temperature was stable at around $32.5{ }^{\circ} \mathrm{C}$ and $30.9^{\circ} \mathrm{C}$ in

\footnotetext{
* Correspondence: julie.renberg@sintef.no

'Department of Health Research, SINTEF Technology and Society,

Trondheim, Norway

Full list of author information is available at the end of the article
}

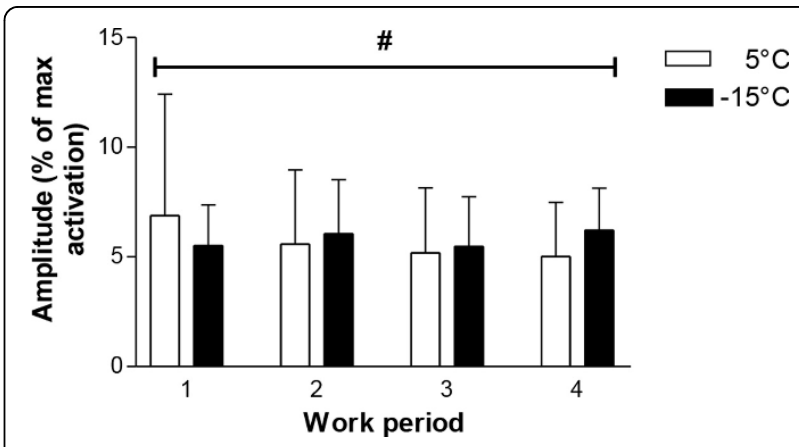

Figure 1 Mean amplitude (\% of max activation) in right flexor digitorum superficialis: manual work hip height for work period 1, 2, 3, and 4. \# significant interaction effect between $T_{a}$ and time. Data is presented as mean (SD) $(N=13)$.

$5{ }^{\circ} \mathrm{C}$ and $-15{ }^{\circ} \mathrm{C}$, respectively. No differences in either $\mathrm{T}_{\mathrm{re}}$ or HR between the $T_{a}$ were observed. There was a significant interaction effect between $T_{a}$ and time at the experiment in EMG activity (Figure 1). Deoxygenation during DWF was significantly more pronounced at $5{ }^{\circ} \mathrm{C}$ than -15 ${ }^{\circ} \mathrm{C}$, but no interaction effect was found between $\mathrm{T}_{\mathrm{a}}$ and time.

\section{Discussion}

Even though there was not a large difference in skin temperature at $-15^{\circ}$ and $5{ }^{\circ} \mathrm{C}$, it may have been sufficient to affect muscle function. At $5^{\circ} \mathrm{C}$, there was a gradual reduction in EMG activity, compared to a stable development at $-15{ }^{\circ} \mathrm{C}$. This difference could be related to temperature-dependent co-activation of muscle pairs [1]. More pronounced cooling would probably have had a more detrimental effect on muscle performance.

\section{Conclusion}

This study has demonstrated that realistic cold exposure reduces skin temperatures, particularly in the extremities, while wearing protective clothing used in the mining 
industry. Exposure to $-15{ }^{\circ} \mathrm{C}$ led to increased local muscle activation during manual work at hip height. While the current protective clothing provides sufficient thermal protection with regard to maintaining core temperature, the extremities are liable to become cold. It is therefore, important to focus on cold protection in the extremities in order to maintain miners' comfort and performance.

\section{Authors' details}

'Department of Health Research, SINTEF Technology and Society,

Trondheim, Norway. ${ }^{2}$ Department of Neuroscience, Faculty of Medicine,

Norwegian University of Science and Technology, Trondheim, Norway.

Published: 14 September 2015

\section{Reference}

1. Oksa J, et al: Cooling-induced changes in muscular performance and EMG activity of agonist and antagonist muscles. Aviation, space, and environmental medicine 1995, 66(1):26-31.

doi:10.1186/2046-7648-4-S1-A113

Cite this article as: Renberg et al:: Muscle activity during simulated work in the cold. Extreme Physiology \& Medicine 2015 4(Suppl 1):A113.

\section{Submit your next manuscript to BioMed Central} and take full advantage of:

- Convenient online submission

- Thorough peer review

- No space constraints or color figure charges

- Immediate publication on acceptance

- Inclusion in PubMed, CAS, Scopus and Google Scholar

- Research which is freely available for redistribution

Submit your manuscript at www.biomedcentral.com/submit
Ciomed Central 